\title{
Mode of action of unfractionated and low molecular weight Heparins on the generation of thrombin in plasma
}

Citation for published version (APA):

Hemker, H. C., \& Beguin, S. (1990). Mode of action of unfractionated and low molecular weight Heparins on the generation of thrombin in plasma. Haemostasis, 20(Suppl. 1), 81-92.

https://doi.org/10.1159/000216164

Document status and date:

Published: 01/01/1990

DOI:

10.1159/000216164

Document Version:

Other version

Please check the document version of this publication:

- A submitted manuscript is the version of the article upon submission and before peer-review. There can be important differences between the submitted version and the official published version of record.

People interested in the research are advised to contact the author for the final version of the publication, or visit the DOI to the publisher's website.

- The final author version and the galley proof are versions of the publication after peer review.

- The final published version features the final layout of the paper including the volume, issue and page numbers.

Link to publication

\footnotetext{
General rights rights.

- You may freely distribute the URL identifying the publication in the public portal. please follow below link for the End User Agreement:

www.umlib.nl/taverne-license

Take down policy

If you believe that this document breaches copyright please contact us at:

repository@maastrichtuniversity.nl

providing details and we will investigate your claim.
}

Copyright and moral rights for the publications made accessible in the public portal are retained by the authors and/or other copyright owners and it is a condition of accessing publications that users recognise and abide by the legal requirements associated with these

- Users may download and print one copy of any publication from the public portal for the purpose of private study or research.

- You may not further distribute the material or use it for any profit-making activity or commercial gain

If the publication is distributed under the terms of Article 25fa of the Dutch Copyright Act, indicated by the "Taverne" license above, 
Haemostasis

Managing Editor: H.C. Hemker, Maastricht

$\mathbf{R e}$

Pub

305

Prinlmanumsersaus

\title{
Mode of Action of Unfractionated and Low Molecular Weight Heparins on the Generation of Thrombin in Plasma
}

\author{
H.C. Hemker, S. Béguin
}

Department of Biochemistry, University of Limburg, Maastricht, The Netherlands

Key Words. Heparin - Low molecular weight heparin - Thrombin - Pentasaccharide . Platelet factor $4 \cdot$ Feedback thrombin generation - Prothrombin conversion

Abstract. Heparins, unfractionated and low molecular weight, act primarily by their scavenging of thrombin (S-type heparins). Via the feedback effect on factor VIII this has a secondary effect on prothrombin conversion in the intrinsic pathway (activated partial thromboplastin time). The anti-Xa action of a heparin will not significantly inhibit prothrombin conversion, except in the case of ultra low molecular weight heparins (P-type heparins) that have no significant antithrombin activity. These P-type heparins need, therefore, be given at high doses to have an antithrombotic effect. In platelet-rich plasma heparins retard platelet activation by lowering thrombin levels. Activated platelets neutralize up to $0.5 \mathrm{U} / \mathrm{ml}$ of unfractionated heparin, but low molecular weight heparin is much less affected.

All existing evidence, be it clinical, pharmacological, or biochemical, indicates that there is essentially only one efficacious way to prevent and treat thrombosis, i.e., by decreasing the amount of thrombin. It is of minor importance what the mechanism behind the decrease is. It can be the inhibition of thrombin formation, as in oral anticoagulation, as well as the acceleration of thrombin breakdown, as in heparin therapy. As a counterexample one can offer prevention of thrombosis by aspirin [1]. Indeed, this suggests that inhibition of thrombin is not the only possible approach and that there is a place for platelet inhibition. It should not go unnoticed, however, that aspirin, although the best available platelet inhibitor, is about one third as effective as good anticoagulation. Also, although everybody thinks in terms of cyclooxygenase inhibition, it has not been proven that this is the way by which aspirin acts. We do not even exclude the possibility that aspirin acts via the inhibition of platelet-mediated thrombin generation.

Admitting the importance of thrombin does not, at this stage, automatically imply that blood coagulation in the sense of the formation of a fibrin clot is an essential part of thrombus formation. The similarity between a venous thrombus and a clot in a test tube has sufficiently confused the field for the time being. It should be recognized that 
thrombin has multiple actions on other clotting factors, on platelets, and on endothelial cells. A clot is simply the effect of the presence of thrombin under conditions of low or absent flow. In flowing blood, thrombin may still cause a thrombus, without the appearance of fibrin being too obvious.

Stressing the role of thrombin does not automatically mean that the anti-Xa action should be negligible. The only known role of factor $\mathrm{Xa}$ is to activate prothrombin. If factor Xa can be adequately inhibited, as in oral anticoagulation, then this inhibition will somewhat contribute to a lower prothrombin conversion and hence to the inhibition of thrombin formation. The question how far heparins inhibit prothrombin conversion by inhibiting factor $\mathrm{Xa}$ is a different issue that will be addressed later. It will be clear that insight in the mode of action of heparin requires insight in the mechanism of thrombin formation. So we will first discuss thrombin formation.

\section{Mechanism of Thrombin Formation}

\section{Core of the Mechanism}

The main chain of proteolytic activations induced by tissue thromboplastin in blood is (in this and subsequent reaction schemes, the arrow represents proteolytic activation and not chemical conversion, square brackets indicate enzymatically active complexes, $\mathrm{PK}=$ prekallikrein; $\mathrm{TF}=$ tissue factor; $\mathrm{PL}=$ phospholipid, Roman numerals indicate the coagulation factors):

$$
\mathrm{VII} \rightarrow \mathrm{X} \rightarrow \text { II }
$$

For intrinsic coagulation the main chain of activations is:

$$
\mathrm{PK} \rightarrow \mathrm{XII} \rightarrow \mathrm{XI} \rightarrow \mathrm{IX} \rightarrow \mathrm{X} \rightarrow \mathrm{II}
$$

All the nonactivated clotting factors participating in these chains are proenzymes of serine proteases, the activated enzymes consequently are serine proteases. In free aqueous solution, these proteolytic activations can be obtained, but they are accelerated up to 100,000 -fold, however, by the presence of a negatively charged phospholipid surface and specific protein cofactors. To illustrate this mechanism we will take the activation of prothrombin as an example. Factor $\mathrm{X}_{\mathrm{a}}$ is capable to generate thrombin from prothrombin in free solution, but only in a very ineffective mechanism [2-4]. Paphadjopoulos and Hanahan [5] were the first who observed that an active prothrombinase exists only in preparations that contain the three components $X_{a}, V_{a}$, and phospholipid. (The question of factor $V$ activation will be discussed later.) Hemker et al. [6] showed that the generation of prothrombinase activity can be described as the reversible formation of a complex of factors, $\mathrm{X}_{\mathrm{a}}$ and $\mathrm{V}, \mathrm{Ca}^{2+}$ and phospholipid. In a series of very elegant experiments Rosing et al. [7] showed that phospholipid diminishes the $\mathrm{K}_{\mathrm{m}}$ for prothrombin conversion (a typical change would be from 3,000 to $30 \mathrm{nM}$ ), whereas factor $V_{a}$ increases the turnover number $\left(\mathrm{k}_{\text {cat }}\right)$ about 1,000-fold.

In 1967 Hemker and Kahn [8] found that the factor $X$ activating enzyme consists of factors VIII $_{\mathrm{a}}$ and $\mathrm{IX}_{\mathrm{a}}$ and phospholipid, forming a complex completely analogous to the prothrombinase complex. Later, van Dieijen et al. [9] showed that in this complex the kinetic effects of phospholipid (on $\mathrm{K}_{\mathrm{m}}$ ) and factor $\mathrm{VIII}_{\mathrm{a}}$ (on $\mathrm{K}_{\text {cat }}$ ) were similar to those of phospholipid and factor $\mathrm{V}_{\mathrm{a}}$ in the prothrombinase complex. Apart from their kinetic effect on $\mathrm{k}_{\text {cat }}$, factors $\mathrm{V}_{\mathrm{a}}$ and VIII $_{\mathrm{a}}$ also serve to better bind their respective en- 
zymes (factors $\mathrm{X}_{\mathrm{a}}$ and $\mathrm{IX}_{\mathrm{a}}$ ) to phospholipid $[10,11]$.

The available data, mainly from the group of Nemerson [12] indicate clearly that factor VII and tissue thromboplastin form a complex that is again comparable to prothrombinase. We can summarize the reactions of the classical coagulation pathways as follows:

$$
\begin{aligned}
& \text { Extrinsic pathway: } \\
& {[\mathrm{VII}, \mathrm{TF}, \mathrm{PL}] \rightarrow[\mathrm{X}, \mathrm{Va}, \mathrm{PL}] \rightarrow \mathrm{II}} \\
& \text { Intrinsic pathway: } \\
& \mathrm{PK} \rightarrow \mathrm{XII} \rightarrow \mathrm{XI} \rightarrow[\mathrm{IX}, \mathrm{VIII}, \mathrm{PL}] \rightarrow \\
& {[\mathrm{X}, \mathrm{Va}, \mathrm{PL}] \rightarrow \mathrm{II}}
\end{aligned}
$$

In the classical view, contact factors and antihemophilic factors form the intrinsic pathway of thrombin formation, and the importance of the role of the contact factors is derived from the recognized importance of the antihemophilic factors. The activating action of factor VII on factor IX invalidates this argument. The first indications that the action of the antihemophilic factors VIII and IX is not confined to the coagulation pathway started by the contact factors were obtained by Biggs and Nossel [13]. Josso and Prou-Wartelle [14] were the first to postulate that factor VII can activate factor IX, so that the antihemophilic factors play a role in thromboplastin-triggered coagulation. This means that factor $\mathrm{X}$ can be activated either directly by factor VII and tissue thromboplastin or indirectly by factor IX $_{\mathrm{a}}$ (together with factor VIII $_{a}$ ) that, in its turn, has been activated by factor VII. It is easy to see that the function of this pathway will anyhow be dependent upon the amount of thromboplastin available. The contribution of the direct, one-step action of factor VII $_{a}$ on factor $\mathrm{X}_{\mathrm{a}}$ formation will be constant in time and roughly proportional to the concentration of thromboplastin. The contribution via the pathway

$$
\mathrm{VII} \rightarrow \mathrm{IX} \rightarrow \mathrm{X}
$$

will be small at the beginning of the reaction, but will increase proportionally with time as the factor $\mathrm{X}$ activating enzyme (i.e. factor $\mathrm{IX}_{\mathrm{a}}$ ) builds up. The reinforcement loop constituted by the antihemophilic factors was called the Josso loop after its discoverer. As has been demonstrated by $\mathrm{Ma} \mathrm{Xi} \mathrm{[15]} \mathrm{it} \mathrm{will}$ gain in importance when clotting is started by increasingly smaller amounts of thromboplastin.

The early observations on the interconnections between the extrinsic and the intrinsic pathway did not get the attention they deserved until Osterud and Rappaport [16] drew attention to the fact that the factor VIIthromboplastin complex is capable of activating factor IX in a partially purified system. Later, Zur and Nemerson [17], Jesty and Silverberg [18] and Marlar and Griffin [19] established this pathway without any reasonable doubt.

With the recognition of the Josso loop, the ancient contradiction between the clinical importance of the antihemophilic factors (VIII and IX) and the relatively poor importance of the contact factors disappears. This means that tissue factor becomes the only important trigger of coagulation, as long as no foreign surfaces start to play a role.

\section{Feedback Activation}

It is essential for the correct function of the hemostatic mechanism that thrombin formation be precisely controlled. The strong flow at the site of a wound, generated by the blood pressure, makes that thrombin that would be slowly formed, even in mas- 
sive quantities, would be washed away. It, therefore, seems useful that thrombin formation occurs explosively after a given lag time. It is equally essential that this explosion is limited to the site of the trigger, i.e., to the site of the lesion. Otherwise, generalized thrombosis would be the logical consequence of the smallest wound. The strongly nonlinear generation kinetics of thrombin formation is caused by feedback activation, i.e., activation of thrombin formation by thrombin itself. The limitation of the explosion is due to inhibition of the active complexes. This inhibition is sometimes triggered by the activated products, e.g., factor $\mathrm{X}_{\mathrm{a}}$ reacting with the extrinsic pathway inhibitor or thrombin-activating protein $\mathrm{C}$ (see below). This means that besides feedback activation, feedback inhibition also plays an essential role in the coagulation mechanism.

Both factor VIII and factor V have to be activated before they can play their role as a protein cofactor to the clotting enzymes. Thrombin is the enzyme that brings about these activations [20-24].

It has been described that in a human system factor $X_{\mathrm{a}}$ can activate factor VIII [25], but recently the importance of this phenomenon in clotting plasma has been questioned on good grounds [26].

At this moment it is established beyond any reasonable doubt that activation of the factors V and VIII is obligatory for their taking part in the coagulation mechanism. From the work of Hurlet-Birk Jensen et al. [27], it may be concluded that the activation of factors V and VIII does occur in vivo during the time course of normal hemostasis.

Among the proteins released by platelets upon triggering with thrombin are factor $\mathrm{V}$ and heparin-neutralizing proteins (platelet factor 4). The amount of factor $V$ seques- tered in the platelets is roughly $20 \%$ of the amount present in the plasma [28]. Thrombin, that causes the release reaction, will also activate the released factor $V$. It has been shown that this activation rather than the release reaction itself is the rate-limiting factor for the generation of factor $\mathrm{V}$ activity from triggered platelets [29]. The concentration of factor $\mathrm{V}$ in platelet-poor plasma is about $25 \mathrm{nM}$ whereas that of its partner, factor $\mathrm{X}$, is around $200 \mathrm{nM}$. This may lead one to think that the contribution of platelet factor $\mathrm{V}$ may be important in vivo. The aggregation of platelets at sites where the hemostatic mechanism is active will cause a further increase in the platelet factor V-plasma factor $V$ ratio. Still patients with a storage pool deficiency that are unable to release factor $\mathrm{V}$ from their platelets do not have an important hemorrhagic diathesis [30]. It seems that only patients lacking factor $\mathrm{V}$ in both platelets and plasma do show a hemorrhagic syndrome [31]. This may be explained by the generally recognized fact that the normal level of any clotting factor represents a large functional excess. As a rule, the level of any clotting factor must drop significantly below $20 \%$ before a decrease of the clotting function becomes apparent.

A second procoagulant function of platelets, induced by thrombin together with collagen, is the platelet 'flip-flop' reaction discovered by Bevers et al. [32]. This reaction consists of a transbilayer movement of the procoagulant, negatively charged phospholipids (primarily phosphatidylserine) that as a rule are to be found almost exclusively at the inner face of the cell membrane. In the presence of collagen and thrombin, platelets produce this procoagulant phospholipid outside the cell, without the cell being disrupted. The precise molecular mechanism of 
this reaction is not yet clear. Anyhow, platelets thus activated offer large amounts of binding sites for the factors $\mathrm{IX}_{\mathrm{a}}, \mathrm{VIII}_{\mathrm{a}}, \mathrm{X}_{\mathrm{a}}$, and $\mathrm{V}_{\mathrm{a}}$ at their outer surface, so that prothrombinase and the factor $\mathrm{X}$ activating enzyme can readily form there. One patient (Mrs. Scott, USA) has been described [33] in whom this mechanism is defective: she suffers from a mild hemorrhagic diathesis consequently known as Scott syndrome.

It has been reported that collagen-activated platelets can start coagulation via a factor XI dependent mechanism and that adenosine diphosphate activation of platelets triggers coagulation via factor XII [34]. These findings remain to be confirmed. The recent observation that platelets release a potent inhibitor of factor XIa, so that factor IX activation by factor XIa hardly proceeds in the presence of activated platelets [35], makes one doubt the importance of contact activation for in vivo thrombin generation.

The current view on the starting mechanism of coagulation is based on the observation that the proenzyme factor VII has a nonnegligible enzymatic activity [36-38]. Once adsorbed onto tissue thromboplastin, the activity of factor VII is enhanced, so as to become sufficiently important to start the clotting process. It has been observed, however, that there exists a more active form of factor VII, the two-chain factor $\mathrm{VII}_{\mathrm{a}}$. This form can be generated from the one-chain form in a number of different ways. Altman and Hemker [39] showed, as early as 1967 , that the contact activation mechanism can enhance factor VII activity in vitro. The cold activation of factor VII, involving kallikrein and different other proteins, has been well established. It has also been described that factor VII can be activated by factors IX $_{a}$ and $X_{\mathrm{a}}[40,41]$.

\section{Feedback Inactivation}

There are two important mechanisms that depend on the previous activation of a clotting factor and that lead to eventual inhibition of thrombin formation: (1) protein C and protein $S$ dependent inactivation of the factors $\mathrm{V}_{\mathrm{a}}$ and $\mathrm{VIII}_{\mathrm{a}}$ and (2) the extrinsic pathway inhibitor mechanism.

Downstream of a lesion in the vessel wall, there will be a region with intact endothelium. Thrombomodulin [42] occurs at the surface of intact endothelial cells. Thrombin binds with high affinity to this molecule and undergoes a modulation of its specificity. It is no longer capable of any action on the clotting factors I, V, VIII, or XIII. Instead, it becomes capable of activating protein $\mathrm{C}$. Protein C [43] is a vitamin $\mathrm{K}$ dependent proserine prot:ase that, once it is activated by the thrombin-thrombomodulin complex, becomes a potent inactivator of factors $\mathrm{V}_{\mathrm{a}}$ and VIII $_{\mathrm{a}}$. This makes that the survival time of factor Va and factor VIIIa must be very short in a region lined by intact endothelium where thrombin has passed. The action of activated protein $\mathrm{C}$ is markedly enhanced by another vitamin $\mathrm{K}$ dependent factor: protein $\mathrm{S}$.

The extrinsic pathway inhibitor is a circulating plasma protein that also is adsorbed on the endothelial wall. It has the capacity to bind to activated factor $\mathrm{X}$ and to form a complex that is a strong inhibitor of the thromboplastin-factor $\mathrm{VII}_{\mathrm{a}}$ complex. This mechanism makes that tissue factor induced factor $\mathrm{X}$ activation will stop as soon as a sufficient amount of factor $X_{a}$ has been produced. The details of the kinetic consequences of this behavior remain to be investigated. For full details on the extrinsic pathway inhibitor, the reader is referred to the paper by Rapaport [44]. 


\section{Mode of Action of Heparins}

The inactivation of the active serine proteases of blood coagulation is a physiologically important mechanism. Antithrombin III (ATIII) is the main plasma protein responsible for this action [45-47]. Its importance is readily deduced from the fact that a $50 \%$ deficiency state implies a major risk of thrombosis. Also (near) complete deficiency is never seen, probably because it is a lethal mutation. Apart from ATIII, coagulation proteases are to some extent inactivated by $\alpha_{2}$-macroglobulin and other antiproteases such as $\alpha_{1}$-antitrypsin [see ref. 48 for a review]. We determined that ATIII in clotting plasma is responsible for the inhibition of $64 \%$ of the thrombin formed, $\alpha_{2}$-macroglobulin for $23 \%$, and remaining inhibitors for $13 \%$.

Among the antiproteases ATIII is extremely important because of the fact that its activity can be enhanced by heparins which makes it the lever on which this important family of antithrombotic drugs acts. Heparin cofactor II will not contribute to thrombin inactivation under normal circumstances [49]. In spite of its name, it will neither be active in the presence of therapeutic heparin concentrations. It starts to play a role, however, when drugs like dermatan sulfate or pentosan polysulfate are present in the plasma. It is interesting to note that those drugs that act with heparin cofactor II only cannot be overdosed which might be the major cause of their allegedly low hemorrhagic activity. The plasma, concentration of prothrombin is $\sim 2 \mu M$, that of ATIII $\sim 3$, and that of heparin cofactor II $\sim 1 \mu M$. This makes that activated ATIII can kill all the thrombin that might ever be formed, but that in the case of heparin cofactor II activa- tion always half of the thrombin goes unharmed.

As we have discussed before, thrombin will enhance its own formation by activating factors V and VIII as well as platelets. Any inhibition of thrombin formation and any reaction that inactivates thrombin will interfere with this positive feedback. The intricate pathways of coagulation inhibition by heparin are mainly determined by these feeedback effects, as we will now discuss.

\section{Extrinsic System}

Biochemical studies on isolated clotting factors have advanced our knowledge of the coagulation system enormously. One of the major insights that we have obtained in this way is that the complete system is so complex that it will be impossible to predict the effect of e.g., heparin by extrapolating from our knowledge of purified systems. The study of the physiological chemistry of the 'isolated organ' called plasma is a much more complicated matter than the study of purified clotting factors. If we understand what happens in a patient receiving heparin, then there is no alternative, however. One of the problems encountered is that in plasma the effect of heparin on thrombin decay may be accompanied by an effect on prothrombin activation. The observation that the ATIIIheparin complex, especially in the case of low molecular weight heparins, has a definite capacity to inactivate added factor $\mathrm{Xa}$ has led to the assumption that factor Xa inhibition in plasma under the influence of heparin might lead to inhibition of prothrombin conversion. This is not to be taken for granted, however, because it has been shown that the prothrombinase complex is immune to antithrombin action $[50,51]$. 
In order to distinguish between this effect and thrombin decay and a possible effect on thrombin generation, we developed a method to dissect them mathematically [52]. The rationale behind this method is the following: We know that the velocity of thrombin breakdown is linearly proportional to the thrombin concentration. The proportionality constant is $\mathrm{k}_{\mathrm{dec}}$. It varies between $\sim 1$ $\mathrm{min}^{-1}$ for normal plasma without additions to $\sim 6 \mathrm{~min}^{-1}$ when $0.1 \mathrm{U} / \mathrm{ml}$ is present in the plasma. The variation is in good approximation linear with the heparin concentration. This makes that every heparin can be assigned a specific decay constant defined as the increase of $\mathbf{k}_{\mathrm{dec}}$ per microgram per millliliter of heparin in normal plasma. Once $\mathrm{k}_{\mathrm{dec}}$ is known, it is in principle easy to obtain the time course of prothrombin conversion from the time course of thrombin formation. At any point of the thrombin generation curve, we can determine the net rate of thrombin formation ( $\left.v_{\text {exp }}\right)$. We can also calculate the velocity of thrombin breakdown $\left(v_{\mathrm{dec}}=\mathrm{k}_{\mathrm{dec}}\right.$ $X$ thrombin concentration). The sum of both velocities is the velocity of prothrombin conversion. In practise there is the complication of the generation of the amidolytically active thrombin- $\alpha_{2}$-macroglobulin complex. We refer to the original literature to explain how this problem has been solved [52].

Applying this method to a study of the effects of heparins on thrombin generation in plasma, we found that, in the extrinsic system, all heparins act primarily on thrombin breakdown and hardly have an effect on prothrombin conversion $[53,54]$. That is to say that there is an effect, but in our system (and in real life probably) it can hardly be observed because at the concentrations that are necessary to demonstrate, e.g., 50\% inhibi- tion, thrombin inactivation is so high that no thrombin can be measured in the system anyhow. This is equally true for unfractionated low molecular weight heparins [55]. Only heparins that do not affect thrombin breakdown, such as Choay's pentasaccharide, can be added at such high concentrations that important prothrombinase inhibition is observable $[55,56]$.

This seems to be in contradiction to the fact that low molecular weight heparins will preferentially inactivate factor $\mathrm{Xa}$ rather than thrombin, but it is not, when two partners of the tripartite prothrombinase complex are present at a fixed concentration, then the prothrombinase concentration will depend upon the concentration of the third one. It will show saturation kinetics. That is to say that, if the varying concentration is increased, the prothrombinase activity will hyperbolically approach the limit set by the concentration of the rate-limiting partner [6] (see figure 1). Given a plasma concentration of factor $\mathrm{V}$ of $\sim 20 \mathrm{nM}$ and one of factor $\mathrm{X}$ of $\sim 200 \mathrm{n} M$, factor $\mathrm{Va}$ will more readily be rate limiting than factor $\mathrm{Xa}$. Under these circumstances, it is logical that variations in factor $\mathrm{Xa}$ concentrations, such as are brought about by increasing factor Xa breakdown with low molecular weight heparins, will not translate immediately in proportional decreases of prothrombinase activity (fig. 1).

Apart from the fact that factor $\mathrm{Xa}$ evidently is not rate limiting for prothrombinase formation, the comprehension of the importance of the inactivation of factor $\mathrm{Xa}$ by low molecular weight heparins is also hampered by technical problems. The decay of thrombin and factor $\mathrm{Xa}$, as it is usually measured, is only remotely related to the actual decay in plasma. It has been found 


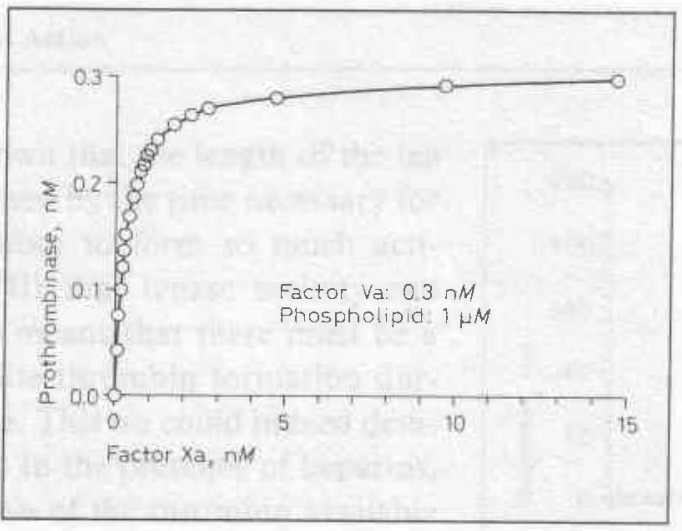

Fig. 1. Prothrombinase activity as a function of factor Xa concentration. The situation at the peak of prothrombinase activity in clotting plasma is mimicked. Factor $\mathrm{Va}$ is rate limiting. Its concentration is sufficiently high to explain the observed rate of prothrombin conversion $(200 \mathrm{n} M / \mathrm{min})$. The observed concentrations of factor $\mathrm{Xa}(>10 \mathrm{nM})$ represent a large excess.

that the $\mathrm{Ca}^{2+}$ concentration has an important influence on the specific decay constants found and that this influence is not the same for every type of heparin. Also there are definite species differences, so that bovine factors in human blood need not necessarily give relevant information.

Recent research work from our group [Wielders and Bendetowicz, unpublished data] has confirmed our earlier notion of the existence of two types of heparin. The S-type heparins in clotting plasma enhance primarily the inactivation of thrombin, whereas the P-type heparins have no or hardly an activity towards this enzyme. Within the S group, the specific decay constants towards thrombin vary relatively little $(<4$-fold) if they are calculated on the basis of the amount of heparin with an high affinity for ATIII. It was surprising to see that the $\mathrm{IC}_{25}$ (the $\mathrm{IC}_{50}$ could for obvious reasons not be measured, see above) did not vary very much between all heparins tested $(<5$ fold).

The picture that seems to develop upon investigation of a large series $(>30)$ of different heparin fractions is that: (1) the amount of ATIII-binding material is roughly proportional to the molecular weight, (2) there is a group of very low molecular weight heparins that does not significantly affect thrombin breakdown in plasma ( $P$ heparins); (3) the specific decay constant for thrombins of the $\mathrm{S}$ heparins (i.e., most heparins in clinical use, inclusively unfractionated heparin) varies only in fourfold range, without clear dependence upon the molecular weight, if expressed in terms of highaffinity material, and (4) the influence of both P- and S-type heparins on prothrombinase is approximately equal and again independent of molecular weight, if expressed in terms of high-affinity material. In S-type heparins this activity is difficult to estimate as it is overshadowed by the antithrombin activity.

It is curious to see that the feedback activation of factor $\mathrm{V}$ by thrombin does not affect the prothrombinase formation in the extrinsic system to any significant extent under our conditions. This is not a new observation because it reflects the well-known fact that the prothrombin time is hardly affected by heparin.

\section{Intrinsic System}

Contrary to the extrinsic system, the intrinsic system does show lag times of thrombin formation that are significantly prolonged by heparin. This is the equivalent of the activated partial thromboplastin time being sensitive to heparin. 
We have shown that the length of the lag time is determined by the time necessary for so much thrombin to form so much activated factor VIII that tenase activity can start [53]. This means that there must be a small but definite thrombin formation during the lag phase. This we could indeed demonstrate (fig. 2). In the presence of heparins, the concentration of the thrombin available during the lag time decreases, so that it will take longer for sufficient factor VIIIa to be activated.

It has been shown that the gèneration of factor IXa is not inhibited by heparin [57]. Factor IXa, although remarkably stable when no heparin is present, is subject to heparin-induced inactivation. If there is a long lag time, factor IXa is 'incubated' during that time with ATIII heparin and proportionally inactivated. The amount of factor IXa that is left when finally enough factor VIIIa is generated to end the lag time, determines the amount of prothrombinase that eventually forms. The action of unfractionated heparin on thrombin, therefore, will be the main factor responsible for the sensitivity of the activated partial thromboplastin time to heparin, whereas its action on factor IXa will contribute to the magnitude of the heparin effect on the total amount of thrombin formed. It must be noted, however, that all inhibitions high in the system will eventually translate in less thrombin, so that it will inhibit any thrombin-mediated effect. A good example is the effect of pentasaccharide in the intrinsic system. Pentasaccharide will have no significant direct effect on thrombin or factor IXa breakdown. Because of its effect on factor $\mathrm{Xa}$, it will cause low ambient concentrations of thrombin during the lag time and, therefore, prolong it [53].

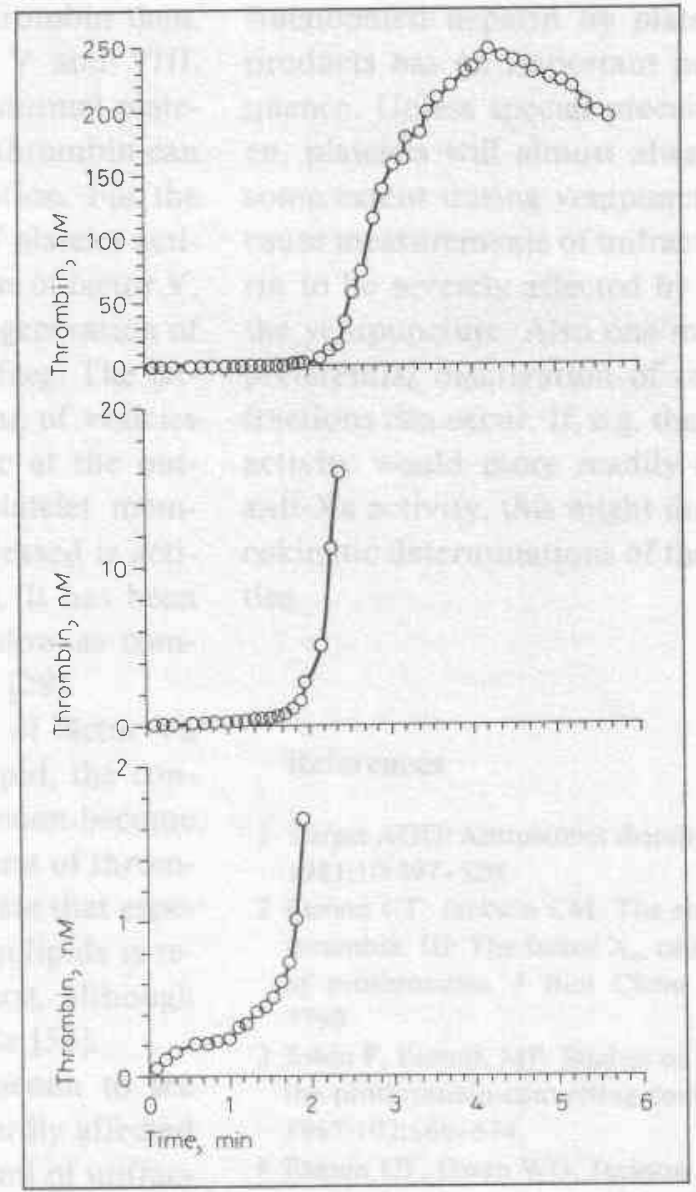

Fig. 2. Thrombin formation during the lag time of intrinsic coagulation. Kaolin and phospholipid are added at zero time together with $\mathrm{Ca}^{2+}$. The three curves represent the same experiment. It is clear that traces of thrombin are formed during the first $2 \mathrm{~min}$ that tend to escape observation, unless special precautions are taken.

\section{Platelet-Rich Plasma}

When clotting is started in platelet-rich plasma, the platelets are not yet activated at the start of the reaction, and the system can be regarded as platelet-poor plasma in which unactivated platelets are suspended. In this 
'platelet-poor plasma' traces of thrombin form in the usual way. This thrombin then, apart from activating factors $\mathrm{V}$ and VIII, also activates the platelets. At normal platelet concentrations $\left(3 \cdot 10^{8} / \mathrm{ml}\right)$, thrombin can bring about full platelet activation. For the clotting system three aspects of platelet activation are of importance: release of factor $\mathrm{V}$, release of platelet factor 4 , and generation of procoagulant phospholipid surface. The latter process consists of shedding of vesicles that exhibit phosphatidylserine at the outside and of flip-flop of the platelet membrane [32]. Factor $V$ that is released is activated by the thrombin present. It has been shown that this activation is slow as compared with the release reaction [29].

Because of the presentation of factor $\mathrm{Va}$ and of procoagulant phospholipid, the conditions for prothrombin conversion become much more favorable, and a burst of thrombin occurs. We could demonstrate that especially the availability of phospholipids is responsible for the thrombin burst, although platelet factor V does contribute [58].

It is an impressive phenomenon to see that the peak of that burst is hardly affected by the presence of up to $0.4 \mathrm{U} / \mathrm{ml}$ of unfractionated heparin! The explanation of this phenomenon is that the heparin-neutralizing material that is shedded by the platelets takes care of the heparin present, so that once thrombin formation has really started, it goes on unhampered. This makes that the only effect of unfractionated heparin on thrombin generation in platelet-rich plasma is prolongation of the lag time. Low molecular weight heparins on the contrary are capable of inhibiting the thrombin peak even in the presence of activated platelets. This may be one of the main differences between unfracionated and low molecular weight heparins [58].
The inactivation of large amounts of unfractionated heparin by platelet activation products has an important practical consequence. Unless special precautions are taken, platelets will almost always activate to some extent during venipuncture. This will cause measurements of unfractionated heparin to be severely affected by the quality of the venipuncture. Also one may ask wether preferential inactivation of certain heparin fractions can occur. If, e.g. the antithrombin activity would more readily neutralize the anti-Xa activity, this might disturb pharmacokinetic determinations of these two activities.

\section{References}

1 Turpie AGG: Antiplatelet therapy. Clin Haematol 1981;10:497-520.

2 Esmon CT, Jackson CM: The conversion of prothrombin. III: The factor $\mathrm{X}_{\mathrm{a}}$, catalyzed activation of prothrombin. J Biol Chem 1974;249:77827790.

3 Jobin F, Esnouf, MP: Studies on the formation of the prothrombin-converting complex. Biochem $J$ 1967;102:666-674.

4 Esmon CT, Owen WG, Jackson CM: A plausible mechanism for prothrombin activation by factor $\mathrm{X}_{\mathrm{a}}$, factor $\mathrm{V}_{\mathrm{a}}$, phospholipid, and calcium ions. $\mathrm{J}$ Biol Chem 1974;249:8045-8047.

5 Papahadjopoulos DP, Hanahan DJ: Observations on the interaction of phospholipids and certain clotting factors in prothrombin activator formation. Biochim Biophys Acta 1964;90:436-439.

6 Hemker HC, Esnouf MP, Hemker PW, Swart ACW, MacFarlane RG: Formation of prothrombin converting activity. Nature 1967;215:248251.

7 Rosing J, Tans G, Govers-Riemslag JWP, Zwaal RFA, Hemker HC: The role of phospholipids and factor $\mathrm{V}_{\mathrm{a}}$ in the prothrombinase complex. J Biol Chem 1980;255:274-283.

8 Hemker HC, Kahn MJP: Reaction sequence of blood coagulation. Nature 1967;215:1201-1202. 
9 van Dieijen G, Tans G, Rosing J, Hemker HC: The role of phospholipid and factor VIII $_{a}$ in the activation of bovine factor X. J Biol Chem 1981; 256:3433-3442.

10 Lindhout T, Govers-Riemslag JWP, van den Waart P, Hemker HC, Rosing J: Factor $\mathrm{V}_{\mathrm{a}}$-factor $\mathrm{X}_{\mathrm{a}}$ interaction. Effects of phospholipid vesicles of varying composition. Biochemistry 1982;21: 5494-5502.

11 van Dieijen G, van Rijn JLML, Govers-Riemslag JWP, Hemker HC, Rosing J: Assembly of the intrinsic factor $\mathrm{X}$ activating complex: Interactions between factor $\mathrm{IX}_{\mathrm{a}}$, factor VIII $_{\mathrm{a}}$, and phospholipid. Thromb Haemost 1985;53:396-400.

12 Silverberg SA, Nemerson Y, Zur M, Ostapchuk P: Kinetics of the activation of bovine coagulation factor X by components of the extrinsic pathway. Kinetic behavior of two-chain factor VII in the presence and absence of tissue factor. J Biol Chem 1977;252:8481-8488.

13 Biggs R, Nossel HL: Tissue extract and the contact reaction in blood coagulation. Thromb Diath Haemorrh 1961;6:1-14.

14 Josso, F, Prou-Wartelle, O: Interaction of Tissue Factor and Factor VII at the earliest phase of coagulation. Thromb Diath Haemorrh 1965;suppl 17:35-44.

$15 \mathrm{MaXi}$, Béguin $\mathrm{S}$, Hemker HC: Importance of factor IX dependent prothrombinase formation The Josso Pathway - in clotting plasma. Haemostasis $1989 ; 301-308$.

16 Osterud B, Rapaport SI: Activation of factor IX by the reaction product of tissue factor and factor VII: Additional pathway for initiating blood coagulation. Proc Natl Acad Sci USA 1977;74:52605264.

17 Zur M, Nemerson Y: Kinetics of factor IX activation via the extrinsic pathway. J Biol Chem 1980; 255:5703-5707.

18 Jesty J, Silverberg SA: Kinetics of the tissue factor-dependent activation of coagulation factors IX and $\mathrm{X}$ in a bovine plasma system. J Biol Chem 1979;254:12337-12345.

19 Marlar RA, Griffin JH: Alternative pathways of thromboplastin-dependent activation of human factor X in plasma. Ann NY Acad Sci 1981;370: 325-335.

20 Newcomb TF, Hoshida M: Factor V and thrombin. Scand J Clin Lab Invest 1965;17(suppl 84): $61-69$.
21 Bergsagel DE, Nockolds ER: The activation of proaccelerin. Br J Hacmatol 1965;11:395-410.

22 Biggs R, MacFarlane RG, Denson KWE, Ash BJ: Thrombin and the interaction of factors VIII and IX. Br J Haematol 1965; 1 1:276-295.

23 Suzuki K, Dahlbäck B, Stenflo J: Thrombin catalyzed activation of human coagulation factor $\mathrm{V}$. J Biol Chem 1982;257:6556-6564.

24 Vehar GA, Davie EW: Preparation and properties of bovine factor VIII (antihemophilic factor). Biochemistry 1980;19:401-410.

25 Mertens K, Bertina RM: Activation of human coagulation factor VIII by activated factor $\mathrm{X}$, the common product of the intrinsic and the extrinsic pathway of blood coagulation. Thromb Haemost 1982;47:96-100.

26 Pieters J, Lindhout T, Hemker HC: In situ generated thrombin is the only enzyme that effectively activates factor VIII and factor V in thromboplastin-activated plasma. Blood 1989:1021-1024.

27 Hurlet-Birk Jensen A, Béguin S, Josso F: Factor V and VIII activation 'in vivo' during bleeding. Evidence of thrombin formation at the early stage of hemostasis. Pathol Biol (Paris) 1976;24:6-10.

28 Tracy PB, Eid LL, Bowie EJW, Mann KG: Radioimmunoassay of factor $\mathrm{V}$ in human plasma and platelets. Blood 1982;60:59-63.

29 Baruch D, Hemker HC, Lindhout T: Kinetics of thrombin induced release and activation of platelet factor V. Eur J Biochem 1986;154:213-218.

30 Weiss HJ, Witte LD, Kaplan KL, et al: Heterogeneity in storage pool deficiency studies of granule bound substances in 18 patients including variants deficient in alpha granules, platelet factor 3 , thromboglobulin and platelet derived growth factor. Blood 1979;54:1296-1319.

31 Tracy PB, Giles AR, Mann KG, Eid LL, Hoogendoorn H, Rivard GE: Factor V (Quebec) a bleeding diathesis associated with a qualitative platelet factor V deficiency. J Clin Invest 1984;74:12211228.

32 Bevers EM, Comfurius P, van Rijn JLML, Hemker HC, Zwaal RFA: Generation of prothrombin-converting activity and the exposure of phosphotidylserine at the outer surface of platelets. Eur J Biochem 1982;122:429-436.

33 Rosing J, Bevers EM, Comfurius P, Hemker HC, van Dieijen $G$, Weiss $H J$, Zwaal RFA: Impaired factor $X$ and prothrombin activation associated with decreased phospholipid exposure in platelets 
from a patient with a bleeding disorder. Blood $1985 ; 65: 1557-1561$.

34 Walsh PN, Griffin JH: Contributions of human platelets to the proteolytic activation of blood coagulation factors XII and XI. Blood 1981;57: 106-118.

35 Soons H: Personal commun.

36 Jesty J, Nemerson Y: Purification of factor VII from bovine plasma. Reaction with tissue factor and activation of factor X. J Biol Chem 1974;249: 509-515.

37 Nemerson Y: Regulation of the initiation of coagulation by factor VII. Haemostasis 1983;13:150155.

38 Nemerson Y: Biological control of factor VII. Thromb Haemost 1976;35:96-100.

39 Altman R, Hemker HC: Contact activation in the extrinsic blood clotting systems. Thromb Diath Haemorrh 1967;18:525-531.

40 Radcliffe R, Nemerson Y: Activation and control of factor VII by activated factor $\mathrm{X}$ and thrombin. Isolation and characterization of a single chain form of factor VII. J Biol Chem 1975;250:388395.

41 Morrisson-Silverberg SA, Jesty J: The role of activated factor $\mathrm{X}$ in the control of bovine coagulation factor VII. J Biol Chem 1981;256:16151630.

42 Esmon CT, Owen WG: Identification of an endothelial cell cofactor for thrombin-catalyzed activation of protein C. Proc Natl Acad Sci USA 1981; 78:2249-2252.

43 Stenflo J: A new vitamin K-dependent protein. Purification from bovine plasma and preliminary characterization. J Biol Chem 1976;251:355363.

44 Rapaport SI: Inhibition of factor VIIa/tissue factor-induced blood coagulation: With particular emphasis upon a factor Xa-dependent inhibitory mechanism. Blood 1989;73:359-365.

45 Abildgaard U: Highly purified antithrombin III with heparin cofactor activity prepared by discelectrophoresis. Scand J Clin Lab Invest 1968;21: 89-91.

46 Biggs R, Denson KWE, Akman N, Borrett R, Hadden M: Antithrombin III, antifactor $\mathrm{X}_{\mathrm{a}}$, and heparin. Br Haematol 1970; 19:283-305.

47 Rosenberg RD, Damus PS: The purification and mechanism of action of human anti-thrombinheparin cofactor. J Biol Chem 1973;248:6490 6505.
48 Travis J, Salvesen GS: Human plasma proteinase inhibitors. Annu Rev Biochem 1984;52:655709.

49 Tollefsen DM, Pestka CA, Monato WJ: Activation of heparin cofactor II by dermatan sulfate. J Biol Chem 1983;258:6713-6716.

50 Marciniak E: Factor $X_{a}$ inactivation by antithrombin III. Evidence for biological stabilization of factor V. J Biol Chem 1973;256:1625-1630.

51 Josso F, Béguin S: Changes in the antithrombin III activity at the interface plasma-phospholipids (abstract). Thromb Haemost 1981;46:285.

52 Hemker HC, Willems G, Béguin S: A computer assisted method to obtain the prothrombin activation velocity in whole plasma independent of thrombin decay processes. Thromb Haemost 1986;56:9-17.

53 Béguin S, Lindhout T, Hemker HC: The mode of action of heparin in plasma. Thromb Haemost 1988;60:457-462.

54 Béguin S, Mardiguian J, Lindhout T, Hemker HC: The mode of action of a low molecular weight heparin preparation (PK10169) and two of its major components on thrombin generation in plasma. Thromb Haemost 1989;61:30-34.

55 Hemker HC: The mode of action of heparin in plasma. XIth Congr Thrombosis and Haemostasis. Leuven, Leuven University Press, 1987, pp 17-36

56 Béguin S, Choay J, Hemker HC: The action of a synthetic pentasaccharide on thrombin generation in whole plasma. Thromb Haemost 1989;61:397401.

57 McNeely TB, Griffith MJ: The anticoagulant mechanism of action of heparin in contact-activated plasma: Inhibition of factor $\mathrm{X}$ activation. Blood 1985;65:1226-1231.

58 Béguin S, Lindhout T, Hemker HC: The effect of trace amounts of tissue factor on thrombin generation in platelet rich plasma; Its inhibition by heparin. Thromb Haemost 1989;61:25-29.

H.C. Hemker, MD

Department of Biochemistry

University of Limburg

NL-6200 MD Maastricht (The Netherlands) 